\title{
Hierarchical Organizations and Shared Responsibilities in the Low-Income Community of Dapeng in Shenzhen, China
}

\author{
Yiwei LIU and Beisi JIA \\ Department of Architecture, The University of Hong Kong \\ Liuyiyi@hku.hk
}

\begin{abstract}
:
Social housing for urban low-income communities is a major problem in Chinese urban housing. In China, standardization without rooms for participation in the current housing construction for low-income communities poses potential hazards to the social and living environments. The controversy over "user participation" in urban and architecture design originated at least 50 years ago when sharing rights and responsibilities were reconsidered. However, solutions that accommodate the need of inhabitants for more rights in making decisions on their own living space in social housing are still lacking. The concept of levels in the built environment was created by Habraken (1972), who aimed to provide a new design methodology that can identify the various responsible parties and their interaction with people, though such a concept can be observed in Chinese vernacular villages, which are often described as inherently flexible. Taking Dapeng as an example, a vernacular village in the suburban area of Shenzhen where the practice of participation of low-income people remains, this paper investigates various hierarchical organizations in the cultural context, village tissue and space hierarchy, building diversity and responsibility distribution of participants. Combined with the current living situation of low-income residents and the social housing dilemma, this paper suggests alternative approaches to achieve balance between professional responsibilities and user rights, and a new perspective on sustainable social housing in China.
\end{abstract}

Key words: Sharing responsibility, hierarchical organization, low-income housing, cooperation

\section{INTRODUCTION}

From a public welfare-oriented housing system under a planned economy to a combination of commercial housing and social housing system under market transition, urban housing in China has experienced a dramatic reform in which the sole right and responsibility in housing construction of the state were transferred to decentralized local governments. To deal with housing shortages in the 1970s, housing reform brought large-scale housing construction in Chinese cities in 1978 and, since then, both housing quantity and quality underwent noticeable improvements. In 1994, the State Council issued the explanatory document "The Decision Making on Deepening the Urban Housing Reform." The document emphasized a dual housing provision system for high-income households that can afford commodity housing, and for middle- or low-income families who can only purchase partial homeownership of affordable social housing. Rapid urbanization led to a shortfall in many aspects in the majority of developing countries, primarily housing (Bredenoord, van Lindert, \& Smets, 2010). In China, the demise of the state's central allocation of housing resources and the autonomy that local governments gained from the state 
marked the start of shared responsibilities in the matter of housing provision, which alleviated the housing shortage problem and largely improved the urban housing quality. Urban homeownership increased rapidly in the emerging housing market, which seems to be successful (Yu, 2006), while the gap widen; that is, housing provision for low-income people faced increasingly severe challenges.

During the past two decades, the changing roles of various parties, such as the state, work units, developers, households, cooperatives and financial institutions, have influenced the housing system (Quan, 2006). In China, there used to be five major measures of housing provision for low-income families, including tax preference, affordable housing, promoting housing cooperative and fund-raising co-housing, low-rent housing, and renovation of old housing (Liu, 2002). However, in practice, Chinese social housing in urban areas consists of two main categories, Economically Affordable Housing and Lowrent Housing (Jia, 2009), which have been poorly implemented due to the reluctance of local governments who took land sales as a "second budget" and the least attractive housing sites that lacked neighborhood facilities (Tang, 2012). In addition to this, the tightly fit functional housing design applied since 1978 has resulted in the unsuitable housing plans for present living conditions and serious housing obsolescence today (Jia, 1998). These conditions intensify the conflict between an increasing number of houseless families and a serious waste of resources. Self-help housing or cooperative housing has recently been discussed in depth, which showing its enormous potential to meet the needs of the urban poor (Bredenoord \& van Lindert, 2010; Fruet, 2005; Jia \& Ren, 2007; Landman \& Napier, 2010; \& Sukumar, 2001), but is rarely mentioned in the Chinese context. Therefore, with respect to answering the housing requirements of low-income families, the provision of social housing is still a huge challenge for China today.

"It is customary to point out how complex the problem of housing is, it is easy to believe the task is really too large and therefore the results will always fall short of our expectations. ... In a situation like that, it is often useful to step back a while and reconsider the premises from where we operate" (Habraken, 2002). Faced with the present social housing issues emerging in the construction, distribution and utilization of affordable housing, we are now trying to improve our institutional guarantee and the management of local governments. However, according to Habraken, it may be better to return to the beginning stage, and rethink and research whether an alternative approach exists to achieve a balanced social housing system that can benefit those who need it most. In other words, if Chinese housing reform in the 1980s owes its first triumph to the decentralization of rights from the state to the local governments, then we can attempt to demonstrate that continuing the promotion of sharing rights and responsibilities in the matter of low-income housing can be a new perspective of sustainable social housing in China. 
As the first completely urbanized city in China, Shenzhen has made great efforts to deal with the housing issue of low-income groups and floating populations. In the past five years, the Shenzhen government built 169,000 houses for about 140,000 statistically low-income households (Shenzhen People's Government Office, 2011). Today, however, the majority of poor families are not living in the social housing provided by local governments, but are instead living together in villages in the suburban area of Shenzhen. This phenomenon deserves great attention but is rarely discussed in existing studies on lowincome housing construction. Simply reducing the housing area cannot solve the problem fundamentally; we need to explore the essence of low-income housing by first answering the question of why low-income people prefer to live in suburban villages rather than in existing social housing.

This paper aims to reveal the character of the low-income community through analyzing the physical character, the distribution of rights and the concept of cooperation in Dapeng village while inspiring a rethinking of the present social housing design methodology in China. With regard to the research methodology, the author adopts urban morphological analysis to determine characteristics of physical environment, and open building theory proposed by John Habraken to identify sharing of rights and responsibilities among people, combined with tactics such as literature review of the concept of levels in open building theory, site visit and a mixture of observation, and interviews with residents and public servants.

Our approach started by interpreting the concept of levels in the built environment and by applying the levels model to analyze low-income urban housing. First, Dapeng village, which belongs to Pengcheng community in the outskirts of Shenzhen, was selected as a typical case. The present population in Dapeng village consists of about $10 \%$ local residents and $90 \%$ migrant residents. Monthly rental is only 100RMB to 500RMB. Next, a survey was conducted in both the physical hierarchical organizations of this vernacular village and the sharing of rights and responsibilities among planners, designers, managers, collectives, local residents and migration families in jointly managing such a low-income community. Factors influencing the variety of housing forms in Dapeng village were studied by a range of sources from the view of urban and architecture design. The whole villages were divided into three parts according to building forms and construction time. Public servants and residents were then interviewed and asked to discuss their working content, living experience and social interaction. Finally, a comparison of inhabitant's participation among housing built around different period in Dapeng village was conducted to explain the interrelationship between inhabitant's participation and the housing cost. This paper attempts to determine the social housing design imperfection in the present china and highlight housing design factors which most influence the low-priced housing and importance of cooperation in urban low-income community. 


\section{CONCEPT OF LEVELS}

The hierarchy of components can be used as a major tool in analyzing towns or housing issues. It is a concept based on the morphological work of the geographer M.R.G. Conzen and a group of architects (Kropf, 1996). Similar to the different working levels of architects and urban designers, the built environment is organized into hierarchical levels, and such concept of levels provides a planning tool to cope with increasingly complex situations (Habraken, 2002). In 1961, in terms of the building life cycle, Habraken proposed two stages of building, the so-called Open Building that divided building components into two levels: support and infill (Habraken, 1972). Forty years later, along with the advancement of urban typological and morphological studies, he extended the concept of levels in the built environment into five levels: urban structure, which refers to major roads and other infrastructures; urban tissue, which includes streets and related urban elements on the scale of the neighborhood; base building, which is the middle level; infill; and furniture (Habraken, 2002). Habraken also discussed seven points of significance of the levels concept: formation of different control distribution patterns, the responsible party on each level is identified, a lower level can be easily changed to make building long lasting, efficient uniformity exists in one part can do many things, easier adaptation on lower levels, capable of responding to local cultures and lifestyles, and users can make decisions on the lower levels.

During the past 50 years, various kinds of levels models were applied in architecture and urban studies by a group of researchers, such as Habraken (2002), Kropf (1996) and, Kendall and Teicher (2000). These levels models were designed to analyze the physical environment and the relationship among the participants. Aside from the five levels proposed by Habraken, Kendall also proposed other levels model that consists of urban structure, urban fabric, base Building, fit-out, furniture and equipment (Kendall \& Teicher, 2000). There is also a seven levels model, which includes level of materials, structures, rooms, buildings, plots, block and streets, and urban tissue. We can see a clear development path of the levels concept, which is moving toward systematic knowledge in the built environment and social content; if we look further, we can find more of types of levels model. In different housing cases, the way of sharing rights and responsibilities among different parties can be observed in the levels model, such that a sophisticated situation can be examined through comparing these models in a systematic manner. For instance, Figure 1, shows observe various degrees of participation of users and professionals in mass housing, "Sites and Services" project, "core houses" project and co-housing. 


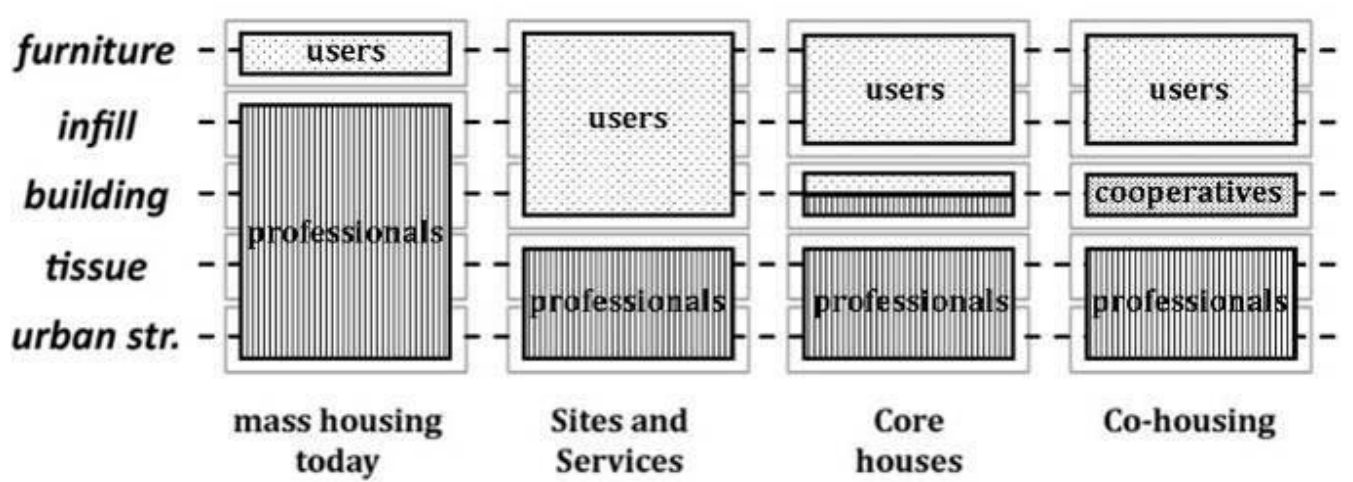

Figure 1 Levels model of shared responsibilities in four different housing types

Source: Adapted from Habraken (1972)

In ordinary mass housing construction today, professional parties are in charge of all the basic levels of urban structure, tissue, base building and even infill parts, such as space function, partition position, and pipeline layout. In comparison, inhabitants can only make decisions on the furniture and equipment level, such as wall colors and simple decoration. This kind of responsibility distribution means housing cannot satisfy the changeable living requirements of inhabitants in the future, which directly results in a large amount of housing built since the 1970s being demolished today; worst of all, such distribution is still being applied in the majority of social housing design in China. To provide a decent house for each family and solve the problem of squatter settlements in most developing countries, "Sites and Services" schemes have received wide acknowledgement, by simply providing housing that is affordable to low-income households and can be progressively upgraded over time (Mayo \& Gross, 1987). In the levels-model of "Sites and Services" schemes, the professionals operate on the lower levels of urban structure and tissue while the inhabitants control the building level upwards. People can build their house the way they want, but they will need a longer period and too much effort to build. By comparison, in "core houses" projects, architects just offer the main part of the building so the professionals and users share responsibilities on the building levels at two stages, while in cooperative housing, a special responsible group is formed by the collective of users who are in charge of the entire building level (Habraken, 2002).

Consequently, the distribution of rights and responsibilities give rise to a significant housing diversity, which can be identified by applying a levels-model into housing analysis. The most important thing for us to realize is that such diversity cannot be achieved by the physical design, but by the diversified distribution of rights 


\section{HIERARCHICAL ORGANIZATIONS IN THE VERNACULAR VILLAGE OF DAPENG}

\subsection{Introduction to Dapeng Village}

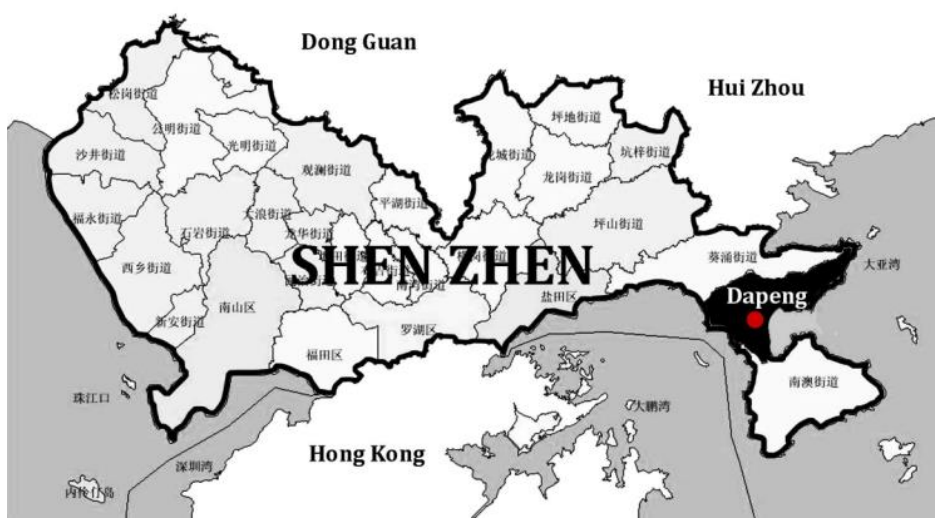

Figure 2: Location of Dapeng sub-district

Source: Adapted from the Administrative Area Plan of Shenzhen

As the origin of Shenzhen, Dapeng village was first built as a military fort during the Ming dynasty and underwent remarkable historical transformation in the past 600 years (Lu, 2007). Dapeng village is one of the 110 vernacular villages located in Dapeng Peninsula which is the eastern coastal area of Shenzhen. It belongs to the Dapeng sub-district, which is the middle part of Dapeng Peninsula (Figure 2). Vernacular villages in this area consist of two main categories, local villages and Hakka villages; Dapeng village is one of the oldest local villages (Wang \& Qiao, 2008).

In the village center is Dapeng Fortress, the political, economic, and military center of Dapeng Peninsula since the Ming dynasty, whose great attraction for the common people gave rise to the village cluster around it and a series of small villages along road sides or based on transport nodes (Wang \& Qiao, 2008). The military function of this fortress ended with the toppling of the Qing dynasty (Lu, 2007). In October 2003, the present Dapeng village, including Dapeng Fortress and several small villages around it, were approved by the State Council as one of the first 12 Chinese historical and cultural villages (PRC Ministry of Construction, 2003). Today, the central part of Dapeng Fortress is planned as a tourism area, and traditional public spaces, such as the Temple of the Queen of Heaven (Tienhou Temple), Confucius Temple and the Granary, have become museums that are open for visitors. However, the hundreds of years old vernacular housing are still used as houses for a large number of low-income people.

\subsection{The Physical Characteristics of Dapeng Village}

To identify the living characteristics of low-income people in Dapeng community, we should first demonstrate the 
physical character of Dapeng village. Kropf proposed that urban tissue offers a clear and explicit method of identifying and describing the physical character of towns, as well as a framework for a rigorous account of character (Kropf, 1996). From the viewpoint of hierarchy, pertinent physical characters of Dapeng village can be specified through observation of the village tissue, which is a synthesis of all the components and can be seen at distinct levels of resolution. At the lower general level, village can be described as an arrangement of streets, blocks, and plots, and higher levels include component buildings, rooms, structures, and materials.

The present Dapeng village includes the central settlement and several small villages around it. This area contains 3255 rental houses and 2 enterprises. Migrant residents account for almost $90 \%$ of the village population. Important infrastructure, such as school, kindergarten, and market, are located in the village periphery. Figure 3 shows the boundary of the old town sub-district, Dapeng village and the fortress from inside to outside.

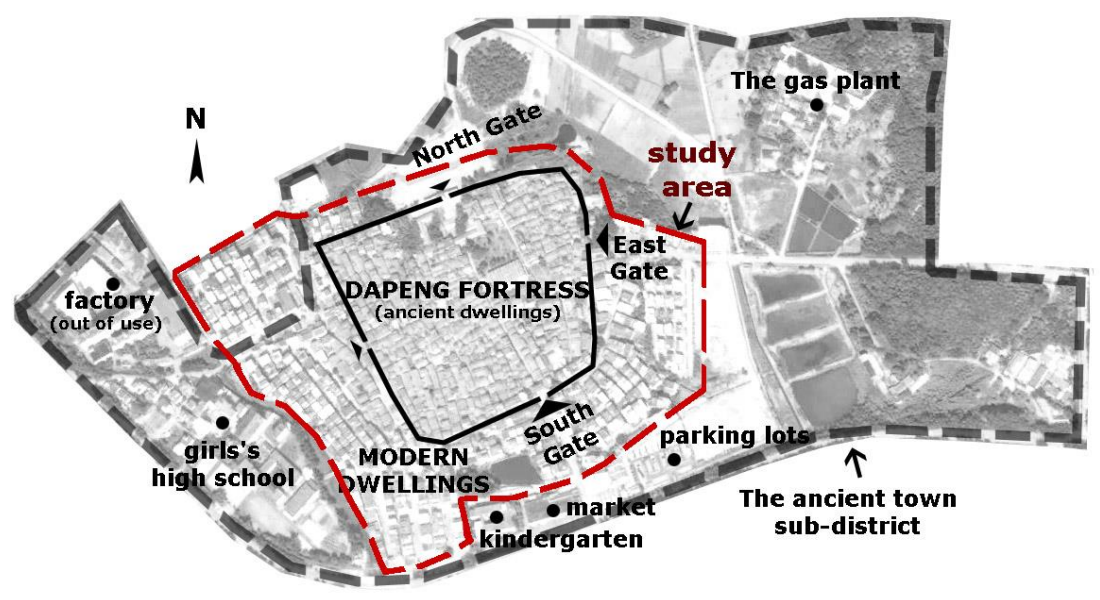

Figure 3: The present Dapeng village area Source: Adapted from Google Map

3.2.1 Variety of village fabric on the tissue level

Time is an important design facet that cannot be ignored in housing. With respect to the level of urban tissue, Figure 4 illustrates the fabric and plot changes, village extension, and space hierarchy along with the transformation of Dapeng village. Today, almost all of the fortress wall and moat were replaced by streets and only a bit of the fortress wall was preserved for visitors. However, the main streets, blocks, and plots of Dapeng Fortress remain relatively unchanged as the central part of the whole village structure.

The contemporary Dapeng village is a composite consisting of four types of tissue. Figure 4 illustrates the specific characteristics of these four types in detail. The first type of tissue comprises the central fortress and the initial settlement, 
which contain the densest housing area and a large open space. Housing in this area has a long life span and shows noticeable marks of self-building. Plots division in the oldest tissue is relatively diverse, whereas the space hierarchy is simple. The village extends to the south of the fortress and forms the second type of tissue. According to an interview with villagers and village managers, housing in this area was basically built in the 1970s. Each house has a similar basal area and height but different plan, and the street extension follows the gentle curve of the south main road. The third type of tissue was formed around 2000s, during which time the government requested each family to select one of several alternative house plans, but villagers can still decide on the building materials and appearances. Housing was arrayed regularly with a more complex space hierarchy than in the second type of tissue, but still kept its identity and features. The latest neighborhood was built around 2005. Every house is nearly the same and can only be distinguished by the color of burglar meshes outside the balconies.
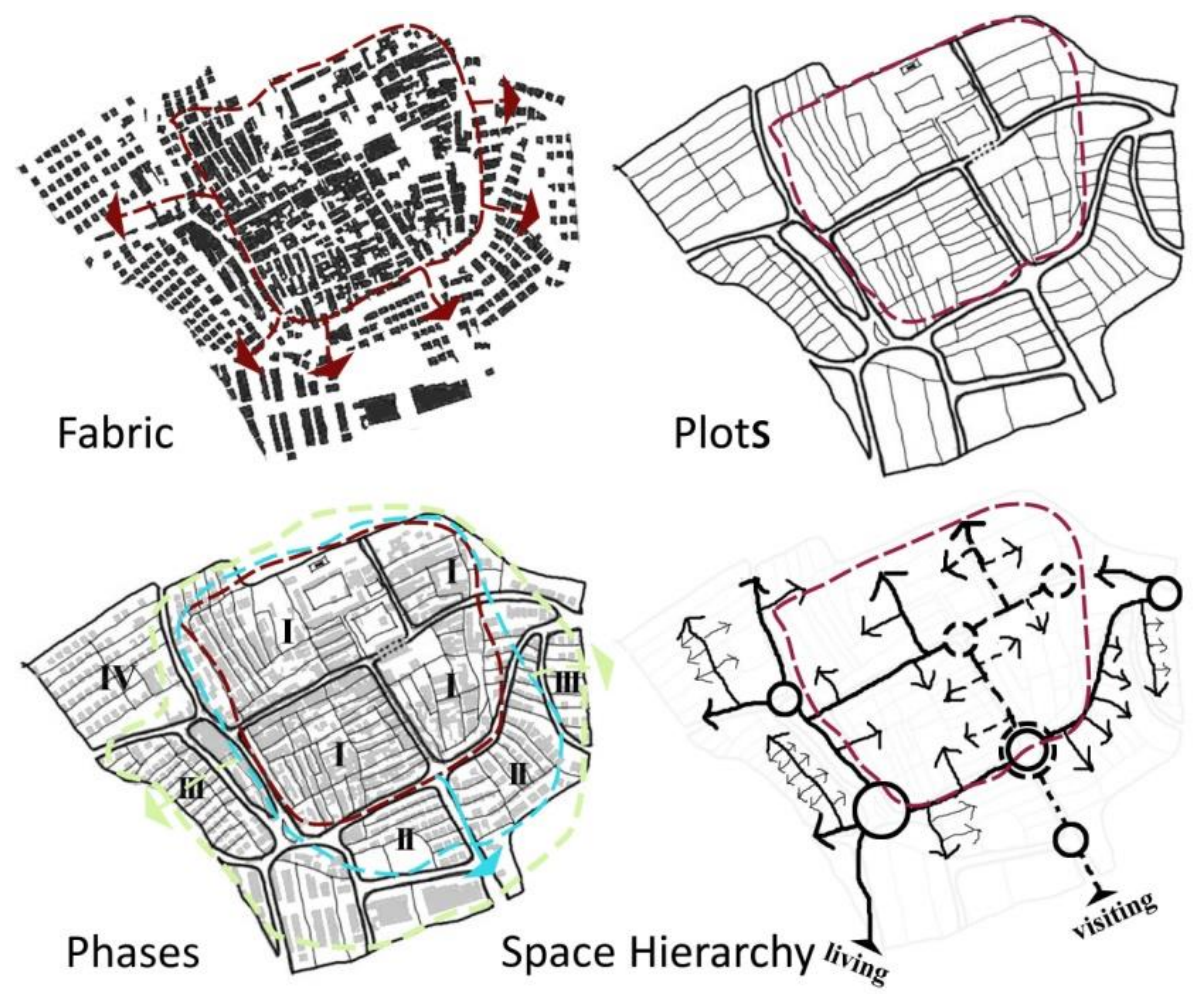

Figure 4: Tissue and space character of Dapeng Village

\subsubsection{Variety of housing types on the building level}

Observing the diverse housing layouts and building forms in each block of Dapeng village, especially in the oldest neighborhood, is not difficult. Figure 5 illustrates the various housing layouts under a potential regulation, where a series of scenarios in the centre part of the village is chosen randomly to show the differences and diversity. 


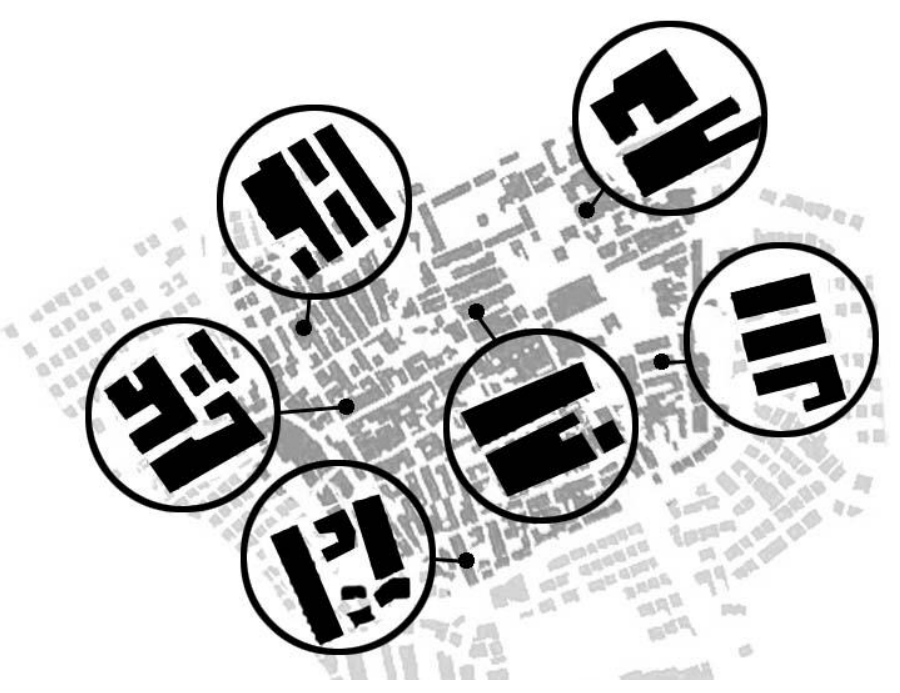

Figure 5: Diverse housing layouts in the central settlements
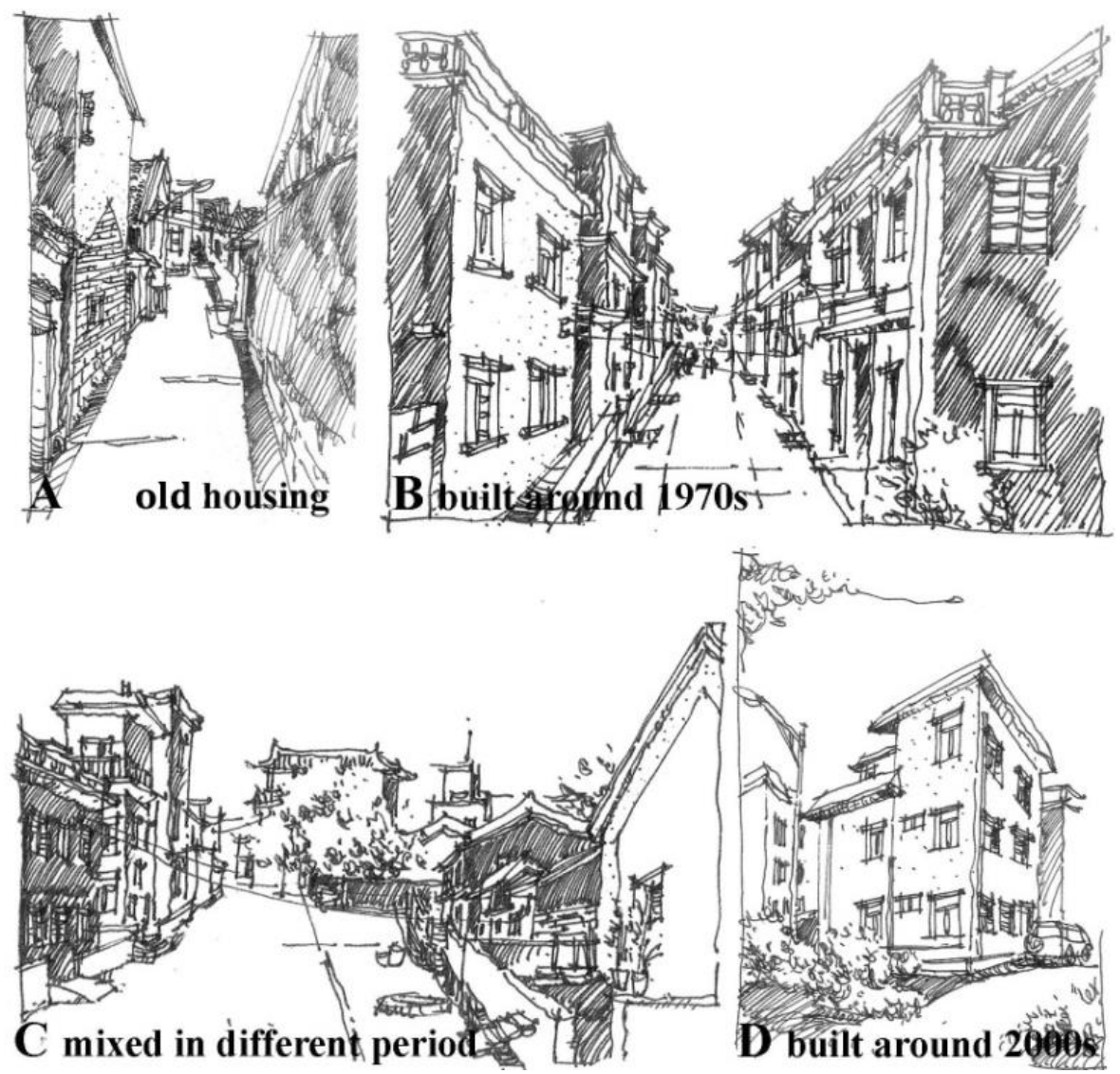

Figure 6: Street-level views of housing in different periods

In Figure 5, it is difficult to find the same two sections of building layout in the central settlements. Various orientations, enclosures of courtyards, and mutual relations lead to the diversity on the neighborhood level. Potential standards perform in a similar scale and density of the building, which are similar by virtue of the standardization of basic structural components. Each plot has its own characteristic and memory, can easily be distinguished, and continues to change. Figure 6 
shows various street-level views of housing in different periods. We have a diverse view of the kinds of streets in Dapeng village and the various building forms along the street. In particular, finding the same two buildings in the central settlements is difficult (Figure 7).

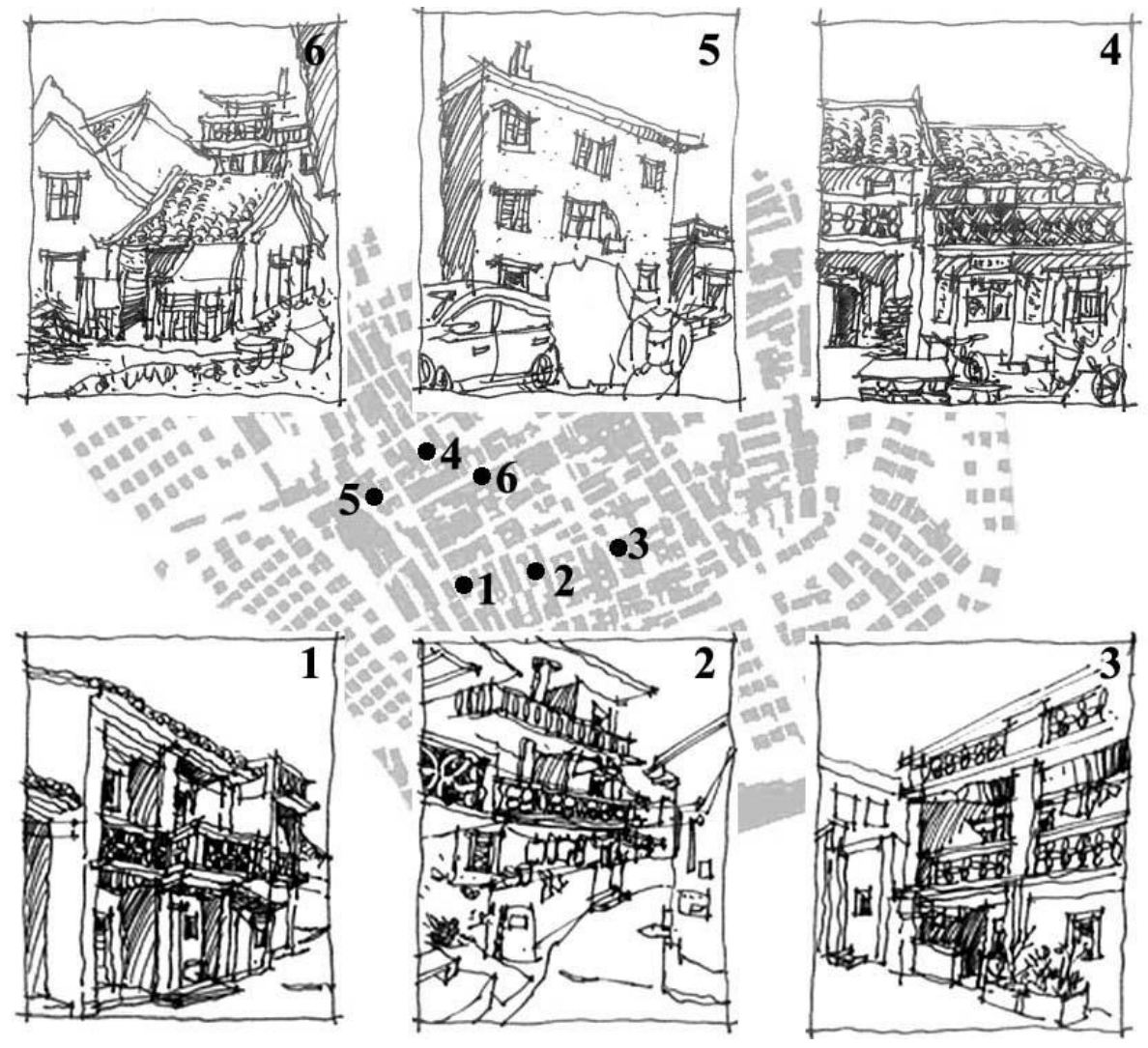

Figure 7: Diverse building appearances in the central settlements

3.2.3 Variety of interior space on the infill level

On the infill level, vernacular housing shows strong flexibility and adaptability, thus offering a great opportunity for people to change the function of the building and adjust the space organization conveniently. In the central settlements, most of the earliest housing type is the traditional terraced house (pai wu), which is one or two story houses with a brick-timber construction and no partitions inside. A typical traditional terraced house can be changed according to the changes in living requirements. Figure 8 shows the ground floor plan of a typical terraced house. In the similar rectangle indoor space, people usually put their kitchen at the back of the house, but the size of the kitchen can be changed by the partition wall. As to the stair case, some families may want to have a bigger living room to play Mahjong, so the stair case can be easily moved to the middle of the room as a spatial partition. In modern life, people find it difficult to put up with public lavatories, so they sometimes create a small space inside the room for a toilet depending on the inhabitants' requirements. Clearly, the inhabitants 
used to build their houses under the exit structure based on their own experience, so the majority of the houses are still available to live in today. With respect to low-income people who are living there, this inherent flexibility allows inhabitants to control the indoor space to their maximum satisfaction. Some of the old houses have even been redesigned as artwork, similar to a museum or a hotel. In Figure 9, four units of a terraced house are changed into three types of rooms in a modern hotel, a two-bed room, a family room and a double-bed room. The area is bigger than that for an ordinary hotel and is easy to divide for various needs.
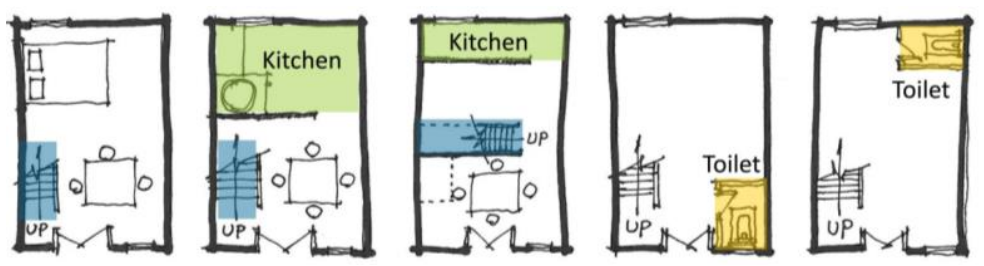

Figure 8: A typical house can be changed according to various living requirements

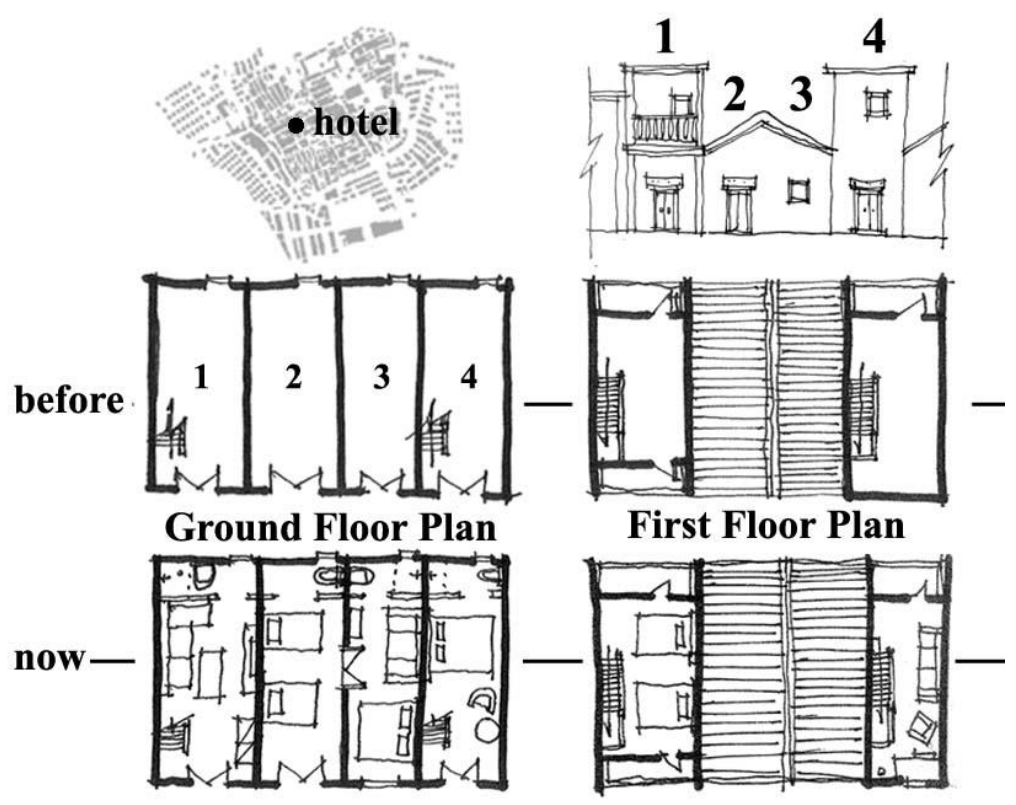

Figure 9: A vernacular house transformed into a modern hotel

\section{DECENTRALIZED RESPONSIBILITIES IN PENGCHENG COMMUNITY}

\subsection{The boundary of rights distribution}

Such a high degree of diversity in different levels of Dapeng village motivates us to search for the power or reason that give rise to such diversity. Physical space is like a city and architecture is a reflection of human behavior. Thus, analyzing the character of a physical space contributes to not only identifying the history, but also to revealing the relationship between 
humans and space.

If we simply divide humans involved in housing construction into two groups, namely, the professional, which includes managers, designers, and landlords who have the right to control an area without living inside, and the inhabitant who is dwelling there, as Habraken did, a levels model can be applied to identify the concept of standardization and the distribution of rights and responsibilities in Dapeng village.

Table 1: Reduction of inhabitants' rights in housing transformation

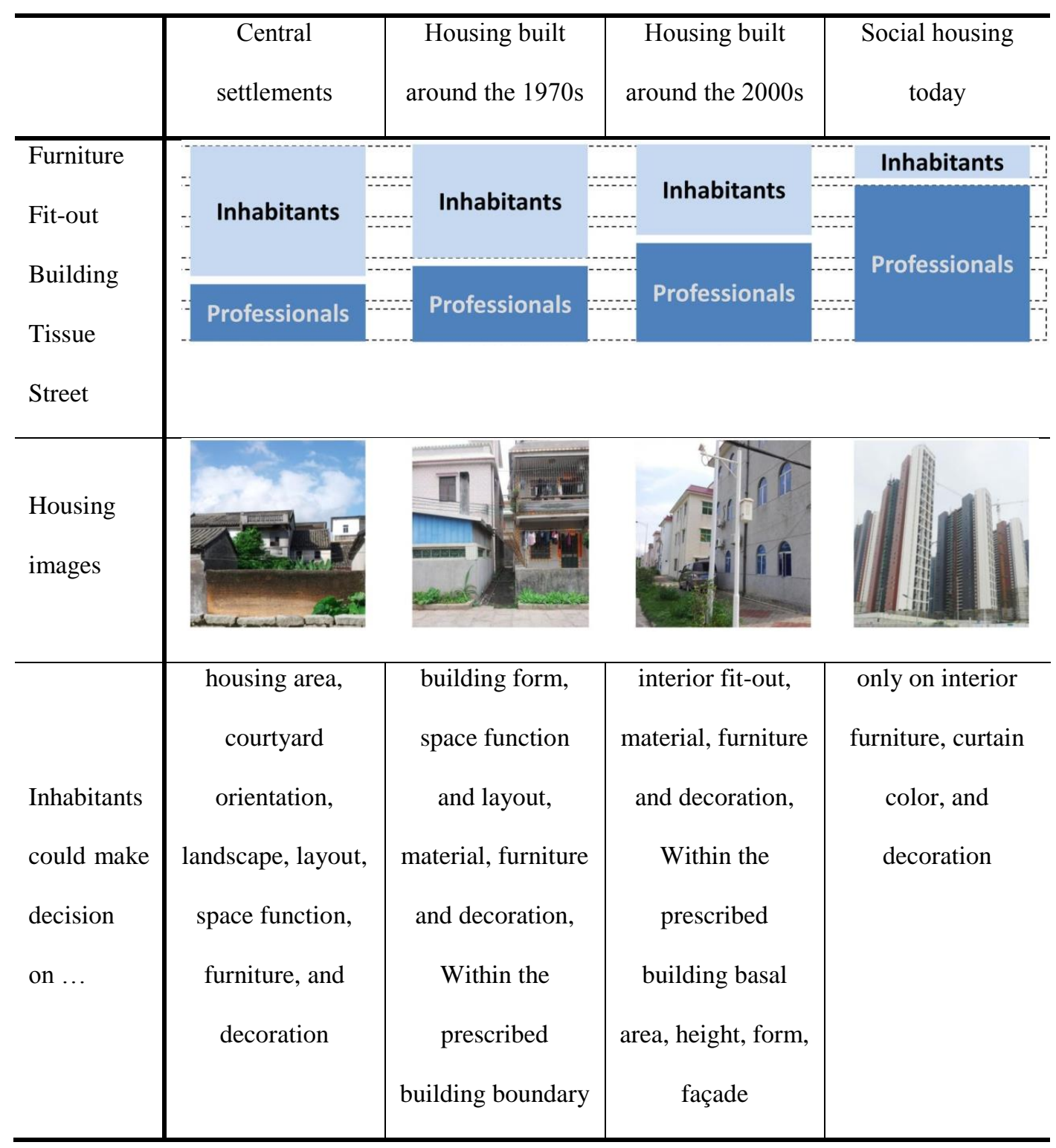

In Table 1, the obvious reduction of inhabitants' rights during the past hundred years can be explained by the levels model. Although there no professional architects and design codes in ancient times, the standardization of basic structural 
components, such as eight ranks "Cai" and eleven ranks "Toukou", and geomantic techniques give rise to the flexibility and adaptability of vernacular housing, as well as inspire housing diversity under potential standards (Jia \& Jiang, 2011). Therefore, inhabitants can decide on the whole process of housing design and construction. People can purchase the land according to what they can afford and adopt the material and courtyard orientation after discussion with Feng-shui masters. Each element in the house can be easily renovated or changed, and the house belongs to just one family. In comparison, housing built around the 1970s still retains the self-built right of inhabitants, but the basal area and building height are constrained. In the 2000s, Shenzhen became the first completely urbanized city in China. Housing built during this period started to be controlled by a series of design standards, that is, the same plan, façade, form, and structure. However, we can still observe that inhabitants fight for their rights on housing identity through changing the shapes of windows and the color of external walls. The concept of standardization moved from the level of structural components to the level of building, along with the decline of diversified housing forms and inhabitant participation. Unfortunately, inhabitants living in mass housing today can only decide on their interior furniture, curtain color and decorations. In the latest social housing, in order to save money for low-income families, even furniture and equipment are fixed in rooms; people only acquire a private space, a house that is difficult to make into a home. Through a comparison in the levels model, the boundary of rights distribution on the lower levels, such as urban street or tissue, can clearly promote housing diversity, which means the professionals and the governments should give more rights to the inhabitant.

\subsection{Hierarchy of the rights and responsibilities in the present Pengcheng community}

Dapeng village belongs to Pengcheng community. Therefore, we can now also take this community as an example to ascertain how groups of peoples cooperated and worked together. The people who influenced the living environment of Pengcheng community may be classified as follows.

- Tenant: a total of $90 \%$ migrants constitute the largest rights body with minimum rights in Dapeng community. The majority of migrants are workers in the enterprises inside or nearby the village and who are attracted by the lower rental, which is only from $100 \mathrm{RMB}$ to $500 \mathrm{RMB}$ per month. In fact, besides convenient working distance and lowest rental, acceptable living conditions should be a significant reason for people to decide on living here. Achieving these three requirements is a must in studies on solving urban low-income housing problems in China.

- House owner: Local residents have the property right to their own house, and most house owners have already moved to other places and given authority to the Cooperative Corporation to manage their house property in the village. To earn more money from the house, people always rebuild their house with the purpose of letting, and the local government 
normally does not limit the house too much.

- Cooperative Corporation: As collective of the local residents, the stock cooperative corporation is responsible for collective interests for paying regular dividends to local residents. Before the housing market was introduced, it was named as the villagers' committee, which is neither a government organization nor an independent profit institution. Today, the Cooperative Corporation is a profit institution responsible for the management of collective land and housing properties.

- Collective of tenants: On the neighborhood level, the lowest priced initial village area in the central settlement is divided into several small neighborhoods by the collective of tenants, which consists of tenants who need to share the same lavatory (Figure 10). Such small neighborhoods are important to maintain a safe living environment and to create a better relationship among villagers.

- Department of Land Management: An official administrative department that mainly controls the height and occupied area of buildings.

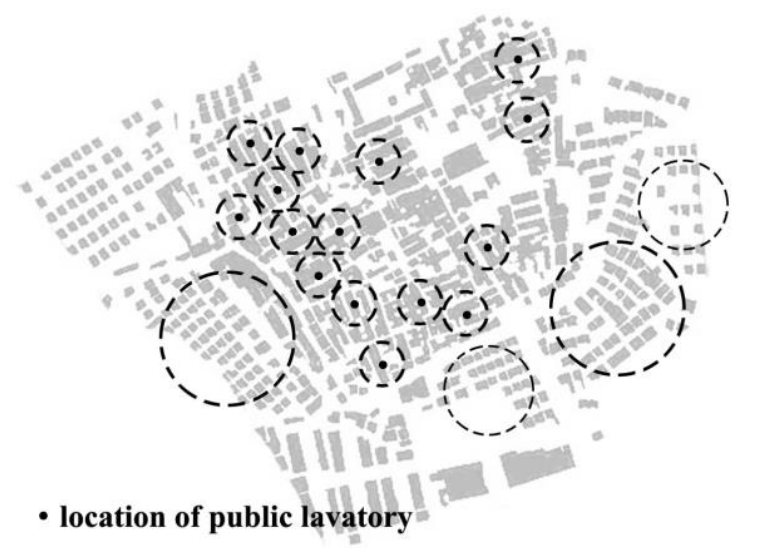

Figure 10: Schematic of neighborhood distribution

In Pengcheng community, we can find that people maintain the balance between affordable rental and acceptable living conditions through cooperation and by sharing rights and responsibilities. Department of Land Management, community management center, Cooperative Corporation, local residents, and migrants play different roles and work together on various levels of the living environment (Figure 11). Even today, local residents still have the right to control the infill part because there is no architecture code for such individually owned housing. 


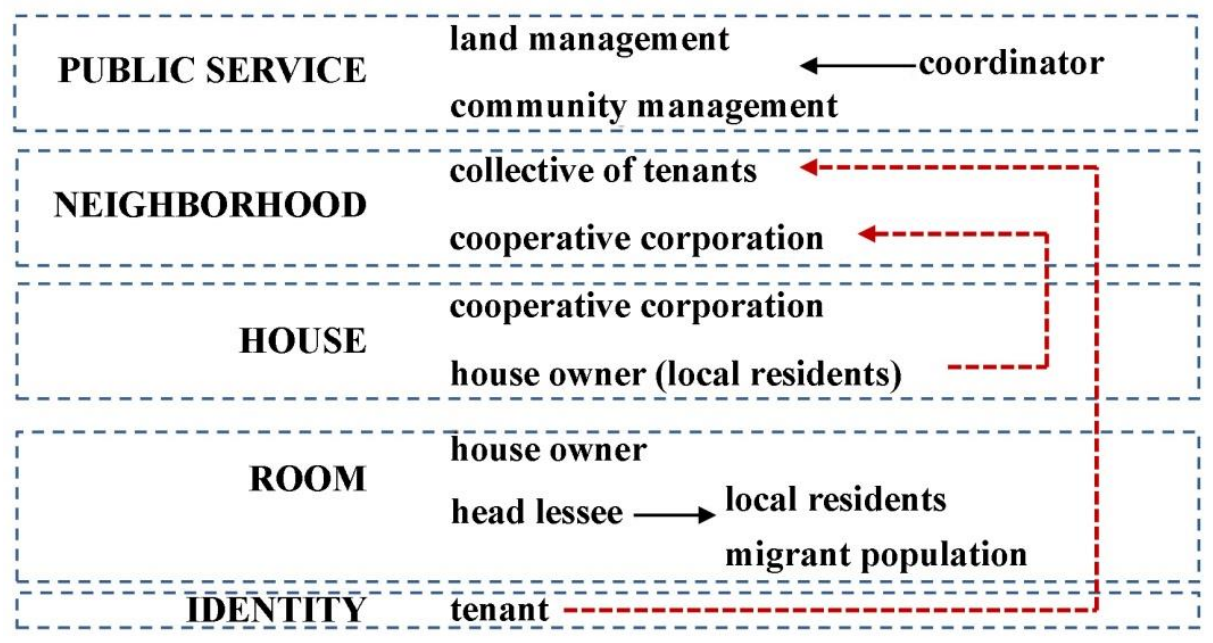

Figure 11: Cooperation and sharing responsibility in Pengcheng community

On the level of urban street, administrative departments of land or community management plays the role of coordinator rather than overseer. They provide public service and control the height and occupied area of buildings; while house owners and tenants still have rights on the tissue and building levels. Therefore, rental in the village is lower and living conditions and the environment are acceptable.

Generally speaking, the decentralization of rights and responsibilities and the cooperation on housing construction lead to the variety and low prices of houses in Dapeng village, which may further inspire us to improve low-income housing design in China.

\section{COMPARISON AND DISCUSSION: APPROACHING LOW-PRICED HOUSING}

\subsection{Convenient interaction with inhabitants}

The rental of urban housing usually depends on the location, construction year and living area. In the central settlement of Pengcheng community, an independent two-storey ancient house featuring the basic living standard system only charges about 100RMB per month, which is equal to $25 \%$ of the minimum living allowance per capita in Shenzhen. This low rental is affordable for almost all the urban families. Without a doubt, social housing is aimed at providing a decent house for everybody, especially the low-income group. In other words, diverse housing types are required for different social groups with varying degrees of demand. Because with the different people in the low-income group, what they can afford also varies. We need to first think about what a decent house means for the very low income group in China, such as the unemployed or laid-off workers. Through a series case study in Pengcheng community, basic characters related to low-priced housing may be generalized. 
- Fundamental living standard: Basic urban water and electricity supply and substantial shelters can satisfy a low-income family.

- Convenient working distance: A short working distance represents a lower cost of transportation and more free time, which is more important than the rental per se for low-income people.

- Flexible living space: Inhabitants have the rights on housing construction and infill layout, so they can adjust their life in a limited indoor space. However, the most important thing is that they may share space, such as the entrance yard and the balcony together, which is a potential enlargement of living space. Ancient housing becomes a core house today, there is no horizontal partition inside of the room, and inhabitants can control the space function through soft techniques.

Consequently, we realized that indoor fit-out flexibility and increased cooperation may help people to gain a decent room and neighborhood at an affordable price. Housing flexibility means people can control their living space as they wish. In other words, the living space can be fully used by tenants, or the house owner can even reorganize the space according to tenant requirements, which ensure that low-income people can always find a decent house here at a decent price. Flexible design is also more economic in the long term due to the increased life span of the building (Schneider \& Till, 2005).

\subsection{Simple housing construction participants}

Participants involved in the whole process of housing construction belong to different responsible parties, such as professionals and users. Compared with the traditional vernacular house, an increase in the number of responsible parties engaged in the housing construction process may give rise to a prolongation of the project cycle and an explosion of housing costs. In terms of the various forms of participants in every stage of housing construction, Table 2 shows the comparison among three settlements built in different periods in Pengcheng Community and social housing in Shenzhen. The comparison focuses on the roles of different responsible parties and the participation of inhabitants.

Table 2: Comparison of participants who engage in every stage of housing construction

\begin{tabular}{|c|c|c|c|c|}
\hline Participants & $\begin{array}{c}\text { Central } \\
\text { settlements }\end{array}$ & $\begin{array}{l}\text { Housing } \\
\text { built around } \\
\text { the } 1970 \mathrm{~s}\end{array}$ & $\begin{array}{l}\text { Housing built } \\
\text { around the } 2000 \mathrm{~s}\end{array}$ & Social housing today \\
\hline Buying Land & Inhabitants & Inhabitants & $\begin{array}{c}\text { Government } \\
+ \\
\text { Collective of } \\
\text { inhabitants } \\
\text { /individuals }\end{array}$ & $\begin{array}{c}\text { Local government } \\
\text { The project owner } \\
\text { Real estate company } \\
+ \\
\text { Administrative Departments }\end{array}$ \\
\hline $\begin{array}{l}\text { Design } \\
\text { process }\end{array}$ & $\begin{array}{c}\text { Inhabitants } \\
+ \\
\text { Feng-shui } \\
\text { Master }\end{array}$ & Inhabitants & $\begin{array}{c}\text { Design company } \\
+ \\
\text { Inhabitants } \\
+\end{array}$ & $\begin{array}{c}\text { Design company } \\
\text { Real estate company } \\
\text { Construction company } \\
+\end{array}$ \\
\hline
\end{tabular}




\begin{tabular}{c|c|c|c|c}
\hline & & Administrative \\
Departments & Administrative Departments \\
$\begin{array}{c}\text { Construction } \\
\text { Process }\end{array}$ & $\begin{array}{c}\text { Inhabitants } \\
+ \\
\text { Craftsman }\end{array}$ & $\begin{array}{c}\text { Inhabitants } \\
+ \\
\text { Construction } \\
\text { team }\end{array}$ & $\begin{array}{c}\text { Inhabitants } \\
+\end{array}$ & $\begin{array}{c}\text { Design company } \\
\text { Construction team } \\
\text { Moving in }\end{array}$ \\
\hline \multirow{2}{*}{$\begin{array}{c}\text { Inhabitants } \\
\text { Construction company } \\
\text { Construction observation }\end{array}$} \\
\hline
\end{tabular}

Simply put, the typical housing construction consists of five stages: obtaining the land, construction financing and designing the house, building the house, selling the house or moving in directly, and managing and maintaining the house every day. With regard to Chinese vernacular housing, inhabitants are in charge of almost everything during the whole process, and some professionals, such as Feng-shui masters or craftsmen only play the role of consultants or workers. The inhabitant is the only decision maker. Before the 2000s, even urban villagers still had land ownership and could build their house without too much constraint. Inhabitants or Cooperative Corporation was the most important part in every stage; they hire the design company and the construction team to build their houses, and the related government administrative department only controlled the building height and the housing appearance along the city's main streets. Inhabitants controlled the cost of housing construction cost in every stage according to what they can afford, which fundamentally determines the lower house prices in most urban villages. Today, with respect to mass housing, complex institutions bring a large number of various participants in every stage of housing construction. A simple house for ordinary people transformed from a natural living space belongs to a family that belongs to a part of the economic market belonging to a government. Thus, housing prices increase dramatically and people lose the right to create affordable and decent living space gradually. The majority of recent urban social housing are constructed as high rise mass housing, and more government administrative departments are engaged in the process of housing distribution. The governments spend a lot of money to reduce the housing rent or price, but people seem to encounter problems in transforming such low-priced buildings into low-priced house. The huge distance between the rich and the poor leads to an increasing number of urban poor and houseless families, which may not be a sustainable approach to building mass social housing with high costing but little profit. Therefore, the main question comes to how the construction cost of social housing can be controlled. The comparison reveals that reducing the participating organizations and allowing 
inhabitants to engage in every stage of the construction should be the first essential step.

\subsection{Cooperation}

Discovering several kinds of cooperation in Dapeng Community is easy. In terms of the low-income community, the cooperation among a collective of tenants can lower the price and still get enough space. In such cases, the cooperation emerges by virtue of the share of a public lavatory, which seems to be the drawback of vernacular housing but lowers the rental maximally. On the other hand, the local residents who own the land, and the Cooperative Corporation that represents the requirements and profits of local residents can decide on their own housing or collective building construction for renting. No additional benefit exists for speculators in the whole transaction process, so the price can be maintained at a low level.

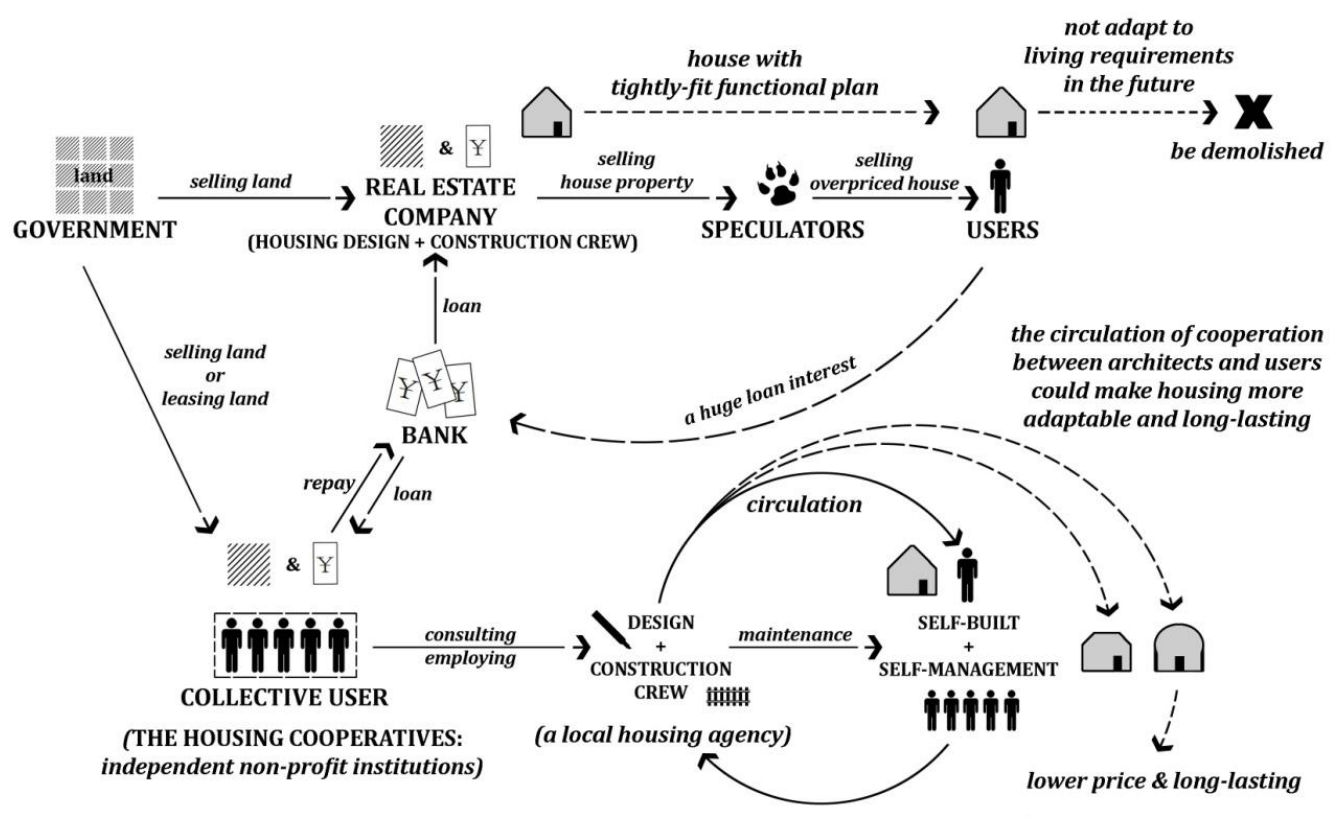

Figure 12: Schematic diagram of the effect of co-housing

The interface between commercial system and public system in housing must be defined (Jia 2009). Cooperative housing (co-housing) is a housing type that is capable of redefining the interface and controlling the high price of housing. It is a popular housing type in western society because it combines the feathers of private and collective ownership and affords its occupants a unity of the strengths of individual proprietorship and the benefits of living in a community with shared living space and activities (Sargisson, 2012). As shown in Figure 12, land can be rented or bought from the government and loans can be applied from banks by an independent non-profit economic entity formed by a collective of users. Such collectives can replace real estate companies in the land transaction and provide housing to the individual directly. Therefore, housing price will be lower because real estate profits and speculators are reduced or even disappear. Self-management by a collective of 
inhabitants will also inspire self-building under a cycle of cooperation between architects and users, which will make housing more adaptable and long-lasting. Actually, co-housing is not a new housing type in China; the first housing cooperative was built in 1986 and experienced about a decade of prosperity, but was rarely adopted recently because of institutional deficiencies, simple types, and lack of knowledge in a specific context (Gu, 2000; Ma, 1986; Wang \& Jin, 2011; \& Xiao, 2000). Nevertheless, the concept of cooperation that co-housing contains is significant for our social housing construction today. Cooperation arises naturally because it is a part of God's design and is inscribed in our human DNA (Manousos, 2012). The essence of cooperation in terms of living environment is the sharing of rights and responsibilities on different levels of the built environment, which can aid in the task of lowering housing price or rental.

\section{CONCLUSIONS}

Intensified housing contradictions exist in Shenzhen for a long time by virtue of the unique geographical location, deep immigration culture and the dramatically development speed. The dilemma facing social housing in Shenzhen today is not just an issue of housing quantity. In past five years, a large amount of social housing was built across Shenzhen but still difficult to benefit those who need it most. A number of urban middle- or low-income families are not satisfied with the social housing which is already assigned to them, some of them even give up the quota and continue to live in urban village which is disappearing gradually in Chinese cities. Similar to the low-income community in Dapeng, Shenzhen, a large number of urban villages in Chinese cities have always played a crucial role in dealing with the housing problem for the urban low-income people. In the case of Shenzhen, compared to constructing a mass of new buildings, improving and activating the living conditions of existed urban villages in Shenzhen may be a more effective way to tackle the shortage of low-priced housing.

A home is more than a roof over one's head. It is a place that can provide a sense of comfort and belonging, as well as elicit feelings of loneliness and fear (McCamant \& Durrett, 1994). Offer urban low-income people a new strange space to replace their conventional living environment may be arbitrary, but to offer them an affordable home and not just a lowerpriced room is significant. The problem of housing is complicated. However, from the viewpoint of architecture design, some potential imperfections of contemporary social housing push us reconsider the premises of urban housing from where we operate. To end this paper, we try to conclude with several inspirations on social housing design in China, especially for lowincome people who look forward to owning or renting a lower-priced house that can be changed easily any time.

- $\quad$ Sharing rights and responsibilities: The decentralization of rights on housing issues is significant for the low-income community, because low-income people are a diversified group, and we cannot use few or even one standard to cope with their various degrees of poverty. Decreasing the housing price by reducing the indoor area seems superficial. Through this 
study, it is demonstrated that low-priced housing for poor families can be achieved through giving more rights to inhabitants themselves and reducing the participation of professionals and speculators on the higher levels (building, infill, etc.) of the built environment.

- $\quad$ Promote social housing diversity: Diversified housing type means more choices for various social classes, who are capable of tackling housing issues with their varying degrees of low income. Reasonable distribution of rights and responsibilities can give rise to such diversity during a long period. Not only the variety of housing forms, but also a dynamic social housing institutional system is required.

- Flexible space design: Good interaction between house and people is a must for a low-income family. People can obtain a decent house only by offering them a house according to their specific requirements and economic affordability. The living space can be fully used by tenants, or the house owner can reorganize the space according to tenant requirements, ensuring that low-income people can always find a decent house at a decent price. In other words, try to give them the right to arrange and adjust their own living space without additional cost.

- Encouragement of cooperation: Encouragement of cooperation on various levels of the built environment is beneficial for decreasing housing price and creating a harmonious community. In addition, it is significant for enlarging the life span of the building, which is a key tactics in approaching lower-price housing because of the decreasing costs of newly built housing. The most important influence is that, as one significant facet of socialism, cooperation in a low-income community may contribute greatly toward achieving more sustainable social housing construction in China.

\section{ACKNOWLEDGMENTS}

The authors would like to express their gratitude to the Graduate School of The University of Hong Kong for providing a comprehensive research platform and various literature materials and to Pengcheng Community Centre for its assistance during their site survey. Appreciation is also extended for the funding provided under the RGC Direct Allocation of The University of Hong Kong for the research project in 2011 - 2013, entitled "The Transformation of Urban Housing Form in the Early Commercial Cities in China." 


\section{REFERENCES}

Bredenoord, J., \& van Lindert, P. (2010). Pro-poor housing policies: Rethinking the potential of assisted self-help housing. Habitat International, 34(3), 278-287.

Bredenoord, J., van Lindert, P., \& Smets, P. (2010). Equal access to shelter: Coping with the urban crisis by supporting selfhelp housing. Habitat International, 34(3), 274-277.

Fruet, G.M. (2005). The low-income housing cooperatives in Porto Alegre, Brazil: A state/community partnership. Habitat International, 29(2), 303-324.

Gu, J. (2000). Problems of chinese cooperative housing. Tianjing: Tianjin people's publisher

Habraken, N.J. (1972). Supports: An alternative to mass housing. London: Architectural press.

Habraken, N.J. (2002). The uses of levels. Open House International, 27(2), 9-20.

Jia, B. (1998). Component strategies for adaptable housing in china. Open House International, 23(1), 4-11

Jia, B. (2009). Defining the interface of the private and the shared—-the cultivation of citizenship in the economical housing. New Architecture, (3), 4-15.

Jia, B., \& Jiang, Y. (2011). Flexibility of traditional buildings and craftsmanship in China. Open House International, 36(4), 20-31.

Jia, B., \& Ren, Z. (2007). Cooperative housing and its practice in Hong Kong. Paper presented at the the 15th Chinese vernacular housing academic conference.

Kendall, S., \& Teicher, J. (2000). Residential open building. New York EF \& N Spon Press.

Kropf, K. (1996). Urban tissue and the character of towns. Urban Design International, 1(3), 247-263.

Landman, K., \& Napier, M. (2010). Waiting for a house or building your own? Reconsidering state provision, aided and unaided self-help in South Africa. Habitat International, 34(3), 299-305.

Liu, Z. (2002). Speech at the international conference of low-income housing development. Chinese and Foreign Real Estate Review, 17, 4-5.

Lu, W. (2007). Research on Dapeng military forts (Suo Cheng). Huazhong Architecture, 25(11), 170-172.

Ma, G. (1986). About the cooperative housing. New Architecture, 1, 65-69.

Manousos, A. (2012). The co-op movement and housing cooperatives. In J. S. Shook (Ed.), Making housing happen: Faithbased affordable housing models (pp. 132). Eugene: Cascade Books.

Mayo, S.K., \& Gross, D.J. (1987). Sites and services -and subsidies: The economics of low-cost housing in developing countries. The World Bank Economic Review, 1(2), 301-335.

McCamant, K., \& Durrett, C. (1994). Cohousing: A contemporary approach to housing ourselves. Berkeley, California: Ten Speed Press.

PRC Ministry of Construction. (2003). The first list of Chinese historical and cultural villages. Beijing: PRC Ministry of Construction

Quan, Z.X. (2006). Institutional transformation and marketisation: The changing patterns of housing investment in urban China. Habitat International, 30(2), 327-341.

Sargisson, L. (2012). Second-wave cohousing: A modern Utopia? Utopian Studies, 23(1). 
Schneider, T., \& Till, J. (2005). Flexible housing: Opportunities and limits. Architectural Research Quarterly, 9(2), 157-166. doi: $10.1017 / \mathrm{S} 1359135505000199$

Shenzhen People's Government Office. (2011). Social housing development scheme in Shenzhen (2011-2015). Shenzhen: Shenzhen People's Government Office.

Sukumar, G. (2001). Institutional potential of housing cooperatives for low-income households: The case of India. Habitat International, 25(2), 147-174.

Tang, B. (2012). Social housing landlord: China. International Encyclopedia of Housing and Home, 432-437.

Wang, L., \& Qiao, X. (2008). A research of vernacular coastal villages on Shenzhen Dapeng peninsula. Nanjing: Southeast University Press.

Wang, S., \& Jin, J. (2011). The development of chinese housing cooperative and thinking over the history and reality. Journal of Socialist Theory Guide, 9, 23.

Xiao, L. (2000). The nature and the future of housing cooperative in China. Chinese and Foreign Real Estate Review 19, 8-9.

Yu, Z. (2006). Heterogeneity and dynamics in China's emerging urban housing market: Two sides of a success story from the late 1990s. Habitat International, 30(2), 277-304. 